A very eminent London pathologist suggested that possibly the gangrene in this case started inside the abdomen high up on the omentum, and I suppose he was thinking of the style of cases described in Felix Lejars's excellent book on Urgent Surgery, 1909. Under the heading of "Torsion of Pedicles" he describes torsion of the great omentum with or without an irredusible hernia. In my case there was no twisted pedicle of omentum, and so I still contend that the gangrene started with the hernia becoming strangulated, and that the gangrene in these cases is capable of passing along the omentum, past the stricture, to the inside of the abdomen, which is not the case as regards strangulated bowel. I do not find anj record of this surgioal point in the textbooks.

\section{A CASE OF TETANUS TREATED BY}

\section{CHLORETONE.}

BX ROLAND A. HOBBS., M.R.C.S.ENG., L.R.C.P.LOND.' HOUSE-SURGEON, ROXAL SURREY COUNTY MOSPITAL, GUIIDFORD.

\author{
With a Note
}

By ERIC W. SHEAF, M.A., M.B., M.C.CantaB. HONORARY ASSISTANT SURGEON, ROYAL SURREY COUNTY HQSPITAL.

THE treatment of tetanus is so very anatisfactory that a case such as the one described below, in which the most dreaded symptoms of the disease were checked, is worthy of notice:

J. A., aged 46, a fishmonger, was admitted to this hospital under Dr. Mitchell, to whom I am indebted for permission to pablish these notes. Dr. Sheaf also watched the case in consultation with Dr. Mitchell.

A nail projecting from his boot cansed an abrasion on the plantar surface of his big toe on January 16th. Rigidity of his jaw doveloped on January 22nd-six days after the injuny $\rightarrow$ and he was admitted to this hospital on January 25th with all the typical symptoms of tetanus except convulsions. The trismus was so advanced that the teeth could only be separated about $\frac{1}{s}$ in.; there was marked abdominal rigidity and dysphagia, stiffness of the neck muscles, and slight retraction.

He was given $100 \mathrm{c.cm}$. of antitetanic serum, fomentations to both feet, as there were abrasions on each, and an injection per rectum of olive oil 3 ij contgining chloretone 30 grains. This was followed by a marked deerease in the rigidity of the jaw; he swallowed much more easily and slept well.

For the next four days his condition remained on the whole satisfactory, although his temperature rose and reached $100.6^{\circ} \mathrm{F}$.

During this period the following doses of chloretone were given, all per rectum, with olive oil.

January $26 \mathrm{th}, 40$ grains, and repeated at night.
January $27 \mathrm{th}, 40$ grains, and repeated at night.
Jannary 28 th, 120 grains, in three doses.
January $29 \mathrm{th}, 80$ grains, in two doses.
January 30 th, 30 grains, early in the morning and
repeated.
100 c.em. of antitetanic serum was irajected on
January 26th.

The cibloretone was given when indicated by an increase in the rigidity.

A marked decrease in the trismus was constantity noticed after every dose of chloretone, the effect being observed at first as early as an hour after the administration of the drug, but later it took about two hours to make any marked aifference.

On January 30 th the throat was getting very full of mucus, which was improved by injections of atropine sulphate Io

Towards the evening he became drowsy and passed into a very heavy and gemicomatose condition, probably due to the effects of the chloretone combined with the severe constitutional disturbanse resulting from the disesse itself.

There were no speciel symptoms of poisoning, but his condition of stupor was somexhat alarming. The temperature now reached its maximum of $102.6^{\circ}$. With the administration of oxygen and strychnine $\frac{1}{30}$ grain alternating every three hours with caffeine 1 grain hypodermically, and continuous saline per rectrm, his condition gradually imaproved.

He was given another $100 \mathrm{c.cm}$. of antitetanic serum. The rigidity never became marked again, and beyond an antitoxin rash he had no untowarả symptoms, and made a rapid recovery, leaving the hospital for the convaleseent home fairly strong, having been in just under six weeks.

The total amounit of antitetanic sarum and chloretone given was: Serum, 390 c.cm. ; chloretone, 420 grains.

To summarize, the points to be specially noted are:

1. The early onset of symptoms and consequent grare prognosis.
2. A marked decrease in the rigidity was noted a definite period after the administration of chloretone, the trismus being relieved in a constant and remarkable manner.

3. The complete absence of convulsions from beginning to end of the illness.

4. The relief of trismus enabled the patient to take ample nourishment throughout and thus maintain his strength.

5. The rapid recovery of the case.

I am firmly convinced that this man's life was saved by chloretone, although the part played by the antitetanic serum must not be disregarded.

Note by Dr. Sheaf.

Tetanus kills partly by the direct action of the toxin and partily by the exhausting effects of the convulsions.

By the trismus, and dread that taking food will bring on a convulsion, starvation is added to the horrors of the disease and sleep is prevented by the painful muscular contraction.

In treating the disease there are therefore the following indications :

1. To prevent further absorption of tissue.

2. To neutralize the circulating toxin, for it is at present impossible to affect the toxin which has already combined with the nerve cells.

3. To relax the museles and prevent the tetanic spasms.

If this last oan be accomplished the patient will escape the exhanstion and be able to take food and to sleep. Consequently he will be in the best position to fight the disease.

To this end many drugs have been used with more or less snccess, and of these magnesium sulphate has recently found most favour.

Dr. C. T. MoClintock and Dr. W. H. Hutchings, of Detroit, Michigan, U.S.A., undertook an experimental study of the various drugs used for this purpose, and were cenvineed that chloretone was the best substanee hitherto employed.

Subsequently Dr. Hutchings published 6 cases treated with chloretone, with 4 recoveries."

Of the 2 cases that died, one succumbed on the eleventh day of peritonitis, having been free from tetanus symptoms for several days; the other was a very severe case, symptoms appearing four days after iajury,

In the next case treatment with chloretone was began; the convialaions were only partially controlled at first, later complate relaxation was obtained, but he died of circulatory failure.

Dr. Hutchings points out that in animal experiments chlor tone poisoning killed by respiratory failure, and that therefore his last case died of tetanus and not of chloretone poisoning. For the same reason I do not think that the serious symptoms on January 30 th in our case were due to maeh to the chloretone 28 to the disease itself.

These results and the result in the case reported above are very antisfactory. Chloretone has the advantage over the intraspinous injection of magnesium salphate in its greater safety, and from these cases its therapentic action seems to be equally satisfactory.

REFERENCE.

1 Surgery, Gynaecology, and Obstetrics, July, 1909.

AN examination of candidates for not fewer than flfteen commissions in the Royal Army Medical Corps will be held on January 25th next and following days. Applications to compete should be made to the Secretary, War Offce, London, S.W., not later than January 16th next, on which date the list will be elosed. The presence of candidates will be required in London from January $23 \mathrm{rd}$.

ALVARENGA PRIZE.- The College of Physieians of Philadelphia announces that the next award of the Alvarenga Prize, being the income for one year of the bequest of the late Senor Alvarenga, and amounting to about 180 dollars, will be made on July 14th, 1911, provided that an essay deemed by the Committee of Award to be worthy of the prize shall have been offered. Essnys, which may be upon any subject in medicine, must be typewritten, and must be received by the Becretary of the College on or before May ist, 1911. The Alvarenga Prize for 1910 has been awarded to Dr. M. Katzenstein, of Berlin, for his essay entitled, The Formation of an Arterial Collateral Circulation in the Kidney. 